\title{
ВОЗМОЖНОСТИ ЭЛЕКТРОРАЗВЕДКИ МЕТОДОМ ЗОНДИРОВАНИЯ СТАНОВЛЕНИЕМ ПОЛЯ В БЛИЖНЕЙ ЗОНЕ ПРИ РЕШЕНИИ НЕФТЕ- ГАЗОПОИСКОВЫХ ЗАДАЧ НА ЮГЕ СИБИРСКОЙ ПЛАТФОРМЫ
}

\author{
И. К. Семинский ${ }^{1,2,3}$, И. В. Буддо ${ }^{1,2,3}$, Е. В. Мурзина ${ }^{1}$, В. А. Селяев ${ }^{2}$ \\ ${ }^{1}$ Институт земной коры СО РАН, г. Иркутск \\ ${ }^{2}$ ООО «СИГМА-ГЕО» г. Иркутск \\ ${ }^{3}$ Иркутский научный центр СО РАН, г. Иркутск \\ Поступила в редакцию 29 февраля 2019 г.
}

\begin{abstract}
Аннотация: в работе рассмотрены горизонтальная и вертикальная разрешаюшая способность метода зондирования становлением поля в ближней зоне (ЗСБ). Указаны возможные способы их численной оченки посредством математического моделирования данных. Наибольшее внимание 8 статье посвящено новому современному способу численной оценки возможностей ЗСБ (в частности, вертикальной разрешающей способности), основанному на многоитеративной инверсии зашумленных синтетических данных. Ключевым моментом предложенного подхода, влияющим на достоверность результатов, является составление физико-геологической модели территории, для которой производится оценка. Физико-геологическая модель составляется на основании априорной информации о геологическом строении территории, данных петрофизики и геофизических исследований скважин. Приведены примеры оченки возможностей ЗСБ при решении нефтегазопоисковых задач для трех осредненных физико-геологических моделей крупных нефтегазовых структур юга Сибирской платформы (Непский и Камовский своды, Ангаро-Ленская ступень). Упомянутые территории характеризуются высокой перспективностью наличия промышленных залежей углеводородов в подсолевой части разреза. Установлено, что метод ЗСБ наиболее эффективен в геологических условиях Непского свода. Посредством применения предложенного подхода появилась возможность численно оченить риски ошибочного геологического прогноза при интерпретации данных ЗСБ на исследуемой территории.

Ключевые слова: Сибирская платформа, петрофизика, пласт-коллектор, электроразведка, зондирование становлением поля в ближней зоне, математическое моделирование, разрешающая способность.
\end{abstract}

\section{APPRAISAL OF THE TRANSIENT ELECTROMAGNETIC METHOD IN THE NEAR FIELD ZONE FOR OIL AND GAS EXPLORATION WITHIN THE SOUTH OF THE SIBERIAN CRATON}

\begin{abstract}
: the paper describes the horizontal and vertical resolution of the transient electromagnetic method in the near field zone (TEM). Possible ways of their numerical evaluation using mathematical data modeling are considered. The most attention in the article is devoted to a new modern method for the numerical evaluation of the TEM capabilities (in particular, vertical resolution), based on the multiiterative inversion of noisy synthetic data. The key point of the proposed approach, which affects the reliability of the results, is the building of a physical-geological model area to study. The physical-geological model is compiled using a priori information about the geological structure of the area, petrophysical data and well-logs. Examples of evaluating capabilities of the TEM for oil and gas exploration are given. Three averaged physical-geological models of large oil and gas structures in the south of the Siberian craton (Nepsky and Kamovsky arches, Angar-Lena stage) are examined. These areas are prospective for oil and gas accumulations in the subsalt part of the section. Shown that the TEM is most effective in the geological settings of the Nepa arch.Through the application of the proposed approach, it became possible to numerically assess the risks of an erroneous geological prediction when interpreting the TEM data. Key words: south of the Siberian craton, petrophysics, reservoir, electromagnetic prospecting, TEM, mathematical modeling, resolution.
\end{abstract}




\section{Введение}

В последние годы задачи, стоящие перед нефтегазовой геофизикой и, в частности, перед электроразведкой, усложнились. Это связано с направленностью современной нефтегазовой политики Российской Федерации на разработку месторождений второй и третьей групп сложности геологического строения. Перед электроразведочным методом ЗСБ (зондирование становлением поля в ближней зоне) стоит задача выделения тонких углеводородонасыщенных (УВ) пластов-коллекторов с изменчивыми коллекторскими свойствами и различным типом флюидонасыщения.

Из вышесказанного ясна актуальность оценки возможностей, а значит разрешающей способности метода ЗСБ при решении нефтегазопоисковых задач в геологических условиях юга Сибирской платформы.

Понятие «разрешающая способность» применительно к ЗСБ позаимствовано из оптической физики и подразумевает способность прибора (или технологии) давать раздельное изображение (отображение) двух близких друг к другу объектов [1]. Вопросами изучения разрешающей способности ЗСБ занимались Матвеев Б. К., Тархов А. Г., Захаркин А. К., Рабинович Б. И., Вахромеев Г. С., Панкратов В. М., Поспеев А. В., Буддо И. В., Гусейнов Р. Г., Семинский И. К. и другие исследователи [2-9].

Разрешающая способность ЗСБ подразделяется на горизонтальную и вертикальную. Ввиду интегральности поля и индивидуальности геоэлектрических условий зондируемой среды, точных формул для оценки горизонтальной и вертикальной разрешающих способностей в методе ЗСБ не существует [3, 10].

Горизонтальная (латеральная) разрешающая способность характеризует точность и детальность ЗСБ при оконтуривании горизонтально простирающихся аномалий и зависит от плотности съемки и латерального размера исследуемых объектов [4].

Для того чтобы оценить горизонтальную разрешающую способность метода ЗСБ, необходимо понять, какой объем зондируемого пространства описы-

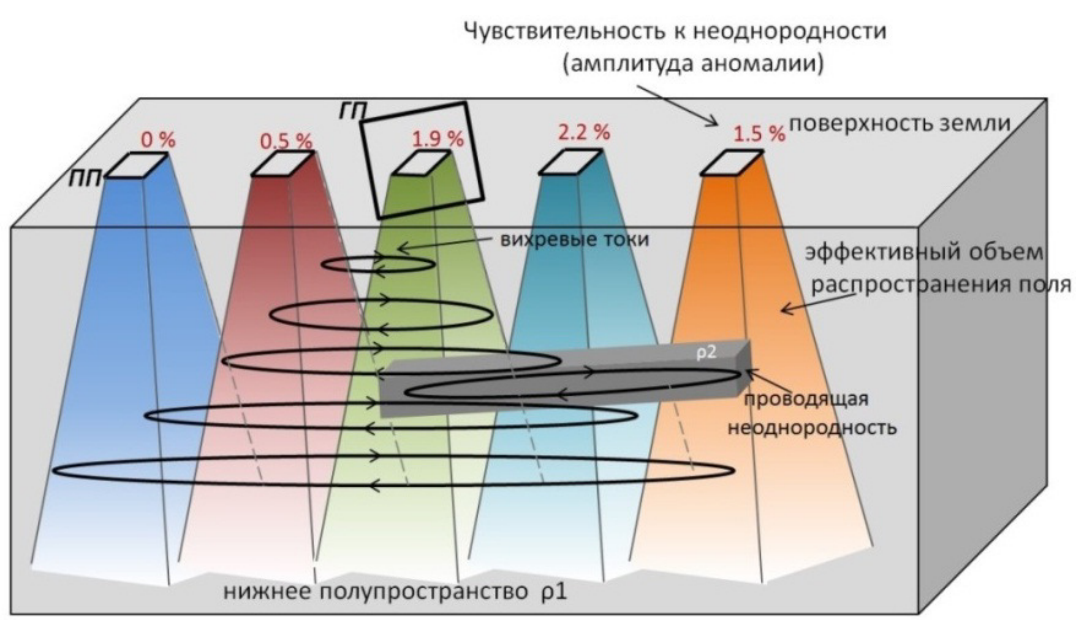

Puc. 1. Схематичное представление установки ЗСБ и области распространения поля. вает сигнал ЗСБ. Применительно к конкретным геоэлектрическим условиям точно оценить размер области, которую описывает конкретный сигнал ЗСБ (эффективный объем распространения поля) [11], возможно только с помощью трехмерного математического моделирования кривых ЗСБ [12].

Согласно Б. К. Матвееву [6], радиус кольца вихревых токов (в определенный момент времени после выключения первичного ЭМ поля, иными словами на определенной глубине), приблизительно равен мощности перекрывающих его отложений.

Для численной оценки горизонтальной разрешающей способности ЗСБ важно знать не только какую область захватывает вторичное ЭМ поле, но и какой объем зондируемого пространства описывает каждая кривая ЗСБ, полученная посредством использования многоразносной установки (сигнал, полученный с помощью одной генераторной петли (ГП), регистрируется на нескольких приемных (ПП)).

Для оценки горизонтальной разрешающей способности в рамках исследования проведено трехмерное математическое моделирование - для многоразносной установки ЗСБ рассчитаны ЭМ отклики от среды, в которую помещен относительно контрастный по геоэлектрическим свойствам объект $\left(\rho_{2}\right)$, и от среды без объекта $\left(\rho_{1}\right)$. Поскольку объект значительно более проводящий, чем вмещающая среда $\left(\rho_{2}<<\rho_{1}\right)$, вихревые токи (составляющее вторичного электромагнитного (ЭМ) поля, спад которого регистрируется на ПП) задерживаются в нем, что создает аномалии ЭМ поля. Далее вычислены расхождения между рассчитанными синтетическими сигналами (рис. 1). Определено, что для приемников ЭМ поля, на которых расхождение стремится к нулю - радиус эффективного объема распространения поля приблизительно равен расстоянию до объекта. Т.е. с увеличением расстояния (шага) между ПП вероятность выделения в разрезе небольших объектов уменьшается, следовательно, ухудшается горизонтальная разрешающая способность.

Для оценки горизонтальной разрешающей способности ЗСБ произведено множество синтетических и практических экспериментов, результаты которых описаны в многочисленных публикациях $[3,5,7,8,9]$. На основании базы трехмерных расчетов для геолого-геоэлектрических условий юга Сибирской платформы установлено, что оптимальным шагом между приемниками ЭМ поля является 400-500 м [9]. Важным фактором для увеличения горизонтальной разрешающей способности метода является применение высокоплотных сетей наблюдения, снижающих эквивалентность решений обратной задачи [13]. 
Вертикальная разрешающая способность характеризует возможности ЗСБ при разделении по геоэлектрическим свойствам горизонтально залегающих слоев и зависит от моментов источника и приемника электромагнитного поля, определяющих отношение сигнал/помеха, а также от геоэлектрических свойств зондируемого пространства.

Для методов электроразведки характерна эквивалентность по $\mathrm{S}$ (проводимости). Суть в том, что можно получить одинаковые значения проводимости слоя при различных сочетаниях его толщины $(\mathrm{H})$ и удельного электрического сопротивления ( $\rho)$. Некоторые исследователи считают, что для выделения тонкого проводящего слоя достаточно, чтобы отклик от него превышал уровень шума на 2-3 \% [5]. Причем возможность его выделения зависит от глубины залегания слоя, его продольной проводимости по отношению к величине суммарной проводимости перекрывающей толщи, его толщины и уровня ЭМ помех района исследования.

Изначально вопрос оценки эквивалентности решений при разделении слоёв рассматривался в 70-ые годы XX века. Л. Л. Ваньяном был предложен алгоритм расчетов примерной зоны эквивалентности, точнее поведения минимума кривых зондирования [14]. Однако ввиду усложнения задач, ставящихся перед ЗСБ, необходимы более точные численные критерии оценки возможностей метода применительно к конкретным геологическим условиям.

Следующим этапом в изучении вертикальной разрешающей способности было математическое моделирование, направленное на непосредственное определение геоэлектрических характеристик тонких коллекторов [2].

При решении задачи разделения двух близкорасположенных слоев необходимо, чтобы они контрастно выделялись по отношению к суммарной проводимости разреза. Результаты математического моделирования показали возможность разделения пластов при проводимости коллектора 10 См. Однако задачу разделения коллекторов на практических кривых $\mathrm{S} \tau(\mathrm{H} \tau)$ при небольшом соотношении глубин залегания терригенного и карбонатного пластов-коллекторов и экранирующем влиянии залегающей выше по разрезу проводящей толщи В. М. Панкратов счел трудновыполнимой.

На основании работ В. М. Панкратова, И. В. Буддо и А. В. Поспеевым были проведены исследования, направленные на определение численных критериев контрастности геоэлектрических свойств пар коллекторов относительно вмещающей среды [15].

В некоторых случаях, в геоэлектрическом разрезе присутствует всего один коллектор, и рассчитать для него коэффициент контрастности не представляется возможным. В этом случае для оценки возможностей ЗСБ применяется математическое моделирование синтетических кривых от заранее известных геологических моделей [8], их зашумление и последующая инверсия.
В качестве способа оценки вертикальной разрешающей способности ЗСБ предлагается применить одномерное синтетическое моделирование кривых ЗСБ и их последующую инверсию, которая позволяет прогнозировать возможность выделения в разрезе определенного геоэлектрического горизонта в зависимости от его емкостных свойств и насыщения, глубины залегания и уровня ЭМ помех исследуемой территории.

\section{Оценка возможностей ЗСБ на юге Сибирской платформы}

Далее приведены примеры численной оценки возможностей метода ЗСБ при решении нефтегазопоисковой задачи для геоэлектрических условий трех крупных нефтегазоносных областей юга Сибирской платформы.

Отличительной особенностью геологического строения юга Сибирской платформы является относительное высокое удельное электрическое сопротивление (УЭС) осадочного чехла и его дифференциация на надсолевую, соленосную и подсолевую части геологического разреза. Наибольшие перспективы наличия углеводородного (УВ) насыщения ассоциируются с подсолевой частью разреза, точнее с породами мотской свиты (или ее аналогами) и/или рифейскими отложениями [16].

В качестве полигонов для одномерного синтетического моделирования были выбраны Непский и Камовский своды, а также Ангаро-Ленская ступень ввиду различного их геологического строения (а значит, и геоэлектрических особенностей). На территории рассматриваемых структурных элементов строения юга Сибирской платформы располагаются такие месторождения нефти и газа, как: Верхнечонское, Тымпучиканское, Вакунайское, Чаяндинское и т.д. (Непский свод); Куюмбинское, Юрубчено-Тохомское, Агалеевское и т.д. (Камовский свод); Ковыктинское, Чиканское, Хандинское и т.д. (Ангаро-Ленская ступень) (рис. 2) [17]. На упомянутых территориях более тридцати лет проводятся исследования методом ЗСБ и имеется значительный фонд пробуренных скважин, исходя из чего несложно составить типовые геологогеоэлектрические модели. Необходимо отметить, что все выбранные модели относятся к классу детерминированных.

Непско-Ботуобинская антеклиза, выделенная по данным геофизики и материалам глубокого бурения, имеет северо-восточное простирание [17]. С юга она ограничена Ангаро-Ленской ступенью, с востока глубоким Прибайкальским прогибом северо-восточного простирания, отделяющим антеклизу от БайкалоПатомской горно-складчатой области. В средней части Непско-Ботуобинской антеклизы по материалам бурения и геофизических исследований выделен Непский свод, являющийся наиболее приподнятой частью антеклизы.

В геологическом строении участка исследования принимают участие протерозойские метаморфические 


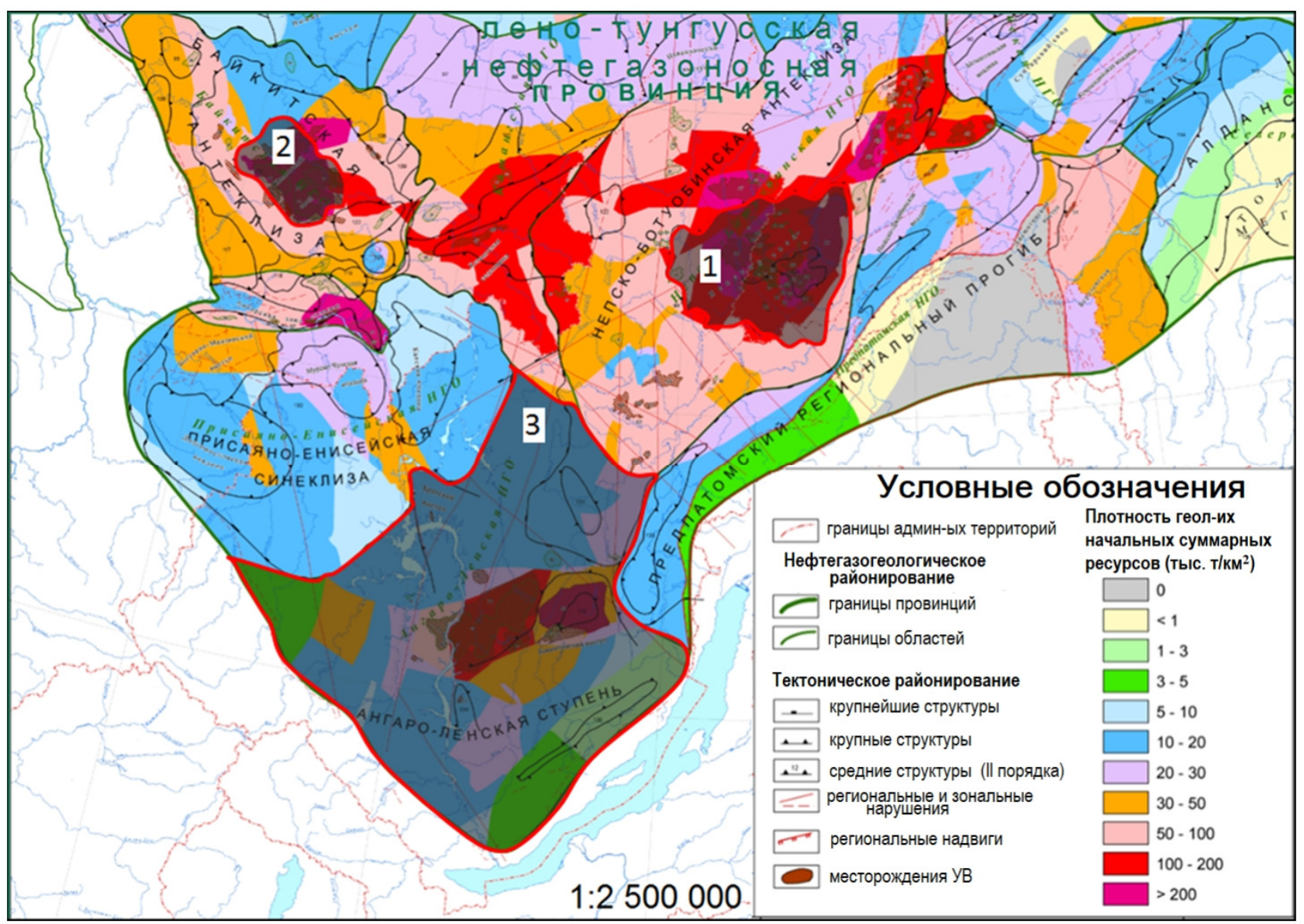

Puc. 2. Фрагмент карты нефтегазоносности Сибирской платформы [18]: 1 - Непский свод; 2 - Камовский свод, 3 - Ангаро-Ленская ступень.

и интрузивные образования кристаллического фундамента, породы венда, кембрийской и ордовикской систем, рыхлые четвертичные образования, а также интрузии трапповой формации пермо-триасового периода.

Обобщенная геолого-геоэлектрическая модель Непского свода представлена на рис. 3 а.

Общая мощность осадочных пород от поверхности кристаллического фундамента до кровли четвертичных отложений достигает 1500-2000 м. Всего в осадочном чехле Непского свода выделяется около 9 геоэлектрических горизонтов, соответствующих илгинской, верхоленской, литвинцевской, ангарской, бельской, булайской, усольской и мотской свитам. Важно отметить, что почти все упомянутые свиты отличаются по своим геоэлектрическим свойствам, это позволяет их уверенно разделить по данным съемки ЗСБ. Исключение составляют только бельская и булайская свиты, близкие по проводимости, вследствие чего они, как правило, объединяются в один геоэлектрический горизонт. Мотская свита, напротив, представлена тремя геоэлектрическими горизонтами, соответствующими нижней, средней и верхней частям свиты.

Промышленные притоки УВ в пределах Непского свода связаны с горизонтами-коллекторами мотской свиты (усть-кутский, преображенский, верхнечонский горизонты), представленной песчаниками, доломита- ми и ангидритами с прослоями кварц-полевошпатовых гравелитов, глинистых доломитов. Среднее удельное электрическое сопротивление нижнемотской подсвиты составляет 30-50 Ом·м.

Для проведения моделирования необходимо знать типичное для условий Непского свода удельное электрическое сопротивление углеводородонасыщенного коллектора, получить которое возможно как из анализа каротажных диаграмм, так и посредством петрофизических расчётов.

Определяющим фактором, отвечающим за УЭС коллектора, является его водонасыщенность. Для расчета удельного электрического сопротивления УВ коллектора целесообразно использовать петрофизическую зависимость Дахнова-Арчи, которая связывает УЭС коллектора и его параметры (коэффициент пористости $\left(K_{n}\right)$ и коэффициент водонасыщенности $\left.\left(K_{6}\right)\right)$ [19].

Петрофизическая модель описывается уравнениями Дахнова-Арчи (1):

$$
P_{n}=\frac{\rho_{\text {вп }}}{\rho_{\text {в }}} ; P_{n}=\frac{\rho_{н n}}{\rho_{\text {вn }}}, \text { (1) }
$$

где $P_{n}$ - параметр пористости, ед.; $P_{H}$ - параметр насыщения, ед.; $\rho_{\text {вn }}-$ УЭС водонасыщенной породы, Ом·м; $\rho_{в}-$ УЭС пластовой воды, Ом•м; $\rho_{н n}-$ УЭС насыщенной породы (УЭС коллектора), Ом·м. 


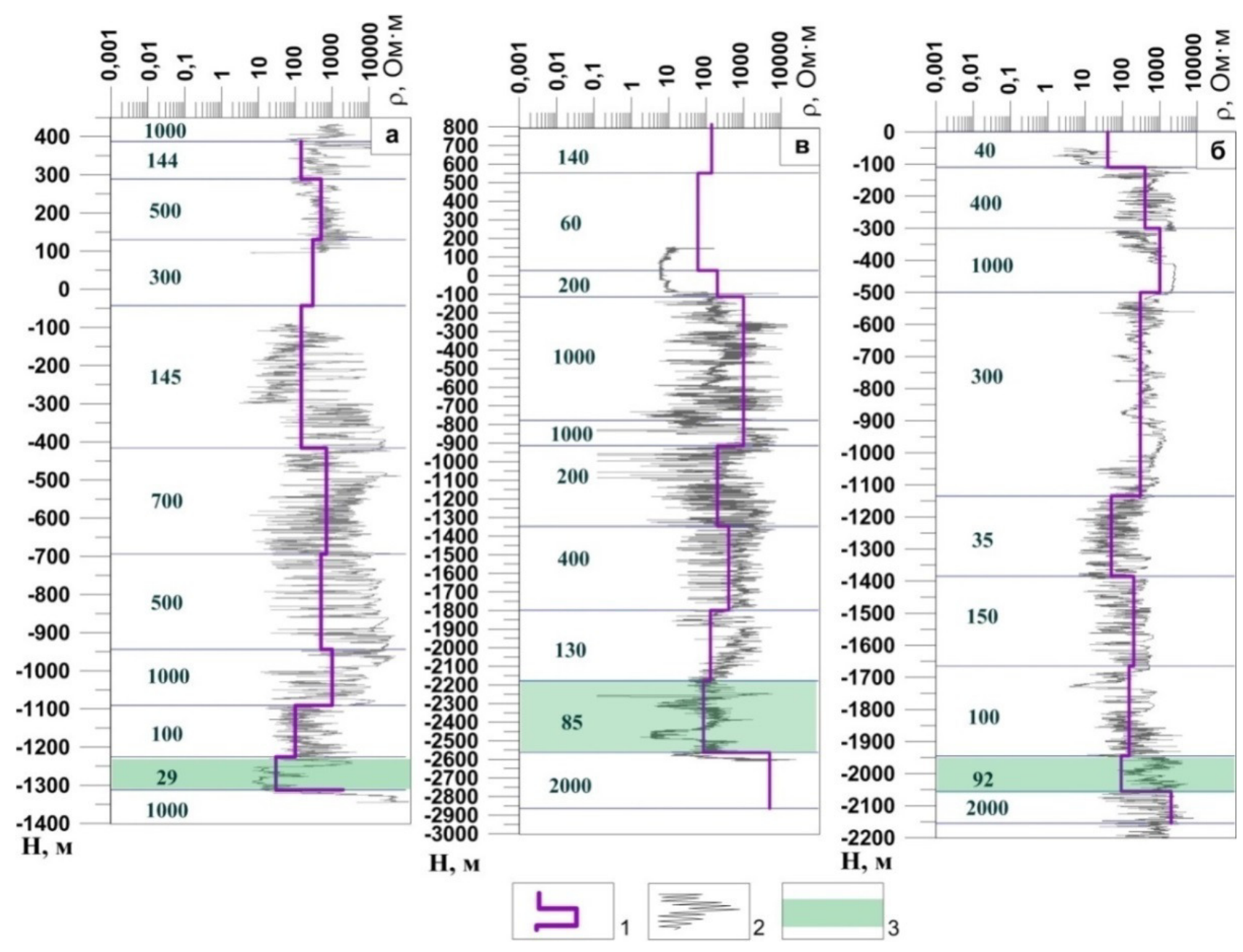

Puc. 3. Типичные геолого-геоэлектрические модели Непского (а) и Камовского сводов (б), и Ангаро-Ленской ступени (в). Условные обозначения: 1 - модель ЗСБ; 2 - диаграмма бокового каротажа; 3 - продуктивная на УВ толща.

Удельное электрическое сопротивление пластовой воды известно по результатам испытания скважин $(0,042$ Ом'м). По результатам петрофизических лабораторных исследований керна известны коэффициент и показатели степени $K_{n}$ и $K_{b}$, описывающие влияние на величину $P_{n}$ формы поровых каналов и характер распределения флюидов в поровом пространстве, соответственно формулам (2).

$$
P_{n}=0,79 \cdot K_{n}^{-1,94} ; \mathrm{P}_{\mathrm{H}}=1,36 \cdot K_{6}^{-1.51}
$$

где $K_{n}$ - коэффициент пористости, \%; $K_{b}$ - коэффициент водонасыщенности, \%.

Из формул расчета параметра пористости и параметра насыщения можно вычислить УЭС насыщенной породы (УЭС коллектора) (3).

$$
\rho_{\text {un }}=P_{n} \cdot P_{H} \cdot \rho_{6}=0,79 \cdot K_{n}^{-1,94} \cdot 1,36 \cdot K_{6}^{-1,51} \cdot 0,042
$$

Подставляя в формулу (3) средневзвешенные значения коэффициента пористости и коэффициента водонасыщенности, рассчитывается УЭС коллектора. По результатам ГИС известно, что для Непского свода типичными являются $K_{n}=9-11 \%$ и $K_{6}=35-50 \%$. Соответствующее указанным параметрам УЭС угле- водородонасыщенного коллектора составляет 8-10 Ом'м. Также, изменяя $K_{6}$, возможно рассчитать УЭС водонасыщенного коллектора. Так, для Непского свода типичный $K_{6}$ водонасыщенного коллектора составляет $80 \%$, следовательно, УЭС - около 4-6 Ом·м. На основании петрофизических зависимостей, зная мощность и УЭС горизонта-коллектора, возможно прогнозировать его емкостные характеристики [7].

Камовский свод является крупнейшим поднятием центральной части Байкитской антеклизы, которая в свою очередь имеет субширотное простирание. C севера Байкитская антеклиза ограничена Курейской синеклизой, с юга - Присаяно-Енисейской синеклизой [17].

В геологическом строении площади принимают участие протерозойские образования фундамента, a также породы, слагающие осадочный чехол позднего протерозоя (рифей, венд), кембрийской, ордовикской, силурийской, каменноугольной, пермской, триасовой, юрской систем, рыхлые четвертичные отложения. Мощность осадочного чехла достигает 4000 м и более. Указанная толщина объясняется присутствием рифейских отложений, с которыми связываются определённые перспективы нефтегазоносности. В 
среднем, в осадочном чехле Камовского свода выделяется около 15 геоэлектрических горизонтов - кроме тех же свит, что слагают осадочных чехол Непского свода, в разрезе присутствуют трапповые интрузии на разном уровне залегания и отложения рифея. Сводная геоэлектрическая модель Камовского свода представлена на рис. 3 б.

Отложения рифея (седановская свита) представлены доломитами и известняками с прослоями аргиллитов и ангидритов. Доломиты зеленоватые, неравномерно чередующиеся с аргиллитами, отмечаются глинисто-доломитовые породы, доломиты с глинистыми включениями, прослои мергелей. Мощность рифейских отложений варьируется от 2000 метров до полного их отсутствия, УЭС от 30 до 200 Ом•м.

Нефтегазоносность исследуемой территории связывается с притоками из рифейских и вендских карбонатных коллекторов (безымянный, боханский, парфеновский). Коллекторы, как правило, представлены доломитами, чередующимися с аргиллитами и прослоями мергелей.

Как упоминалось ранее, для синтетического моделирования необходимо знать удельное сопротивление углеводородонасыщенного коллектора, которое возможно получить путем петрофизических расчетов и анализа результатов бурения. Посредством формул Дахнова-Арчи, приведенных выше, а также зная средние значения $K_{n}(10 \%), K_{6}(20 \%)$ и других петрофизических показателей для рассматриваемой территории, установлено, что типичное удельное сопротивление углеводородонасыщенного коллектора составляет 11-13 Ом·м.

Ангаро-Ленская ступень находится южнее описываемых ранее структур, с юга она ограничена Байкальской складчатостью, с севера - Непско-Ботуобинской антеклизой на востоке и Присаяно-Енисейской синеклизой - на западе [17].

Осадочный чехол рассматриваемой территории сложен породами вендского, нижнекембрийского и кембрийского возраста. В среднем мощность осадочных отложений рассматриваемой территории составляет от 2500 до 3000 м и подразделяется на 7 геоэлектрических горизонтов. К основным перспективным нефтегазоносным объектам в районе относятся песчаные горизонты подсолевого терригенного комплекса: безымянный, боханский и парфёновский. Из них промышленно продуктивными являются песчаники парфеновского горизонта чорской свиты.

Отложения чорской свиты венда представлены неравномерным переслаиванием песчаников, алевролитов и аргиллитов. УЭС чорской свиты изменяется в диапазоне 40-150 Ом·м.

Типичная геоэлектрическая модель АнгароЛенской ступени представлена на рис. 3 в.

Учитывая типичные $K_{n}(14 \%), K_{6}(28 \%)$ и остальные петрофизические показатели, типичное удельное электрическое сопротивление углеводородонасыщенного коллектора в среднем составляет 6-8 Ом·м.

\section{Методика математического моделирования кривых ЗСБ}

Оценка возможностей ЗСБ при изучении коллекторских свойств подсолевой части разреза производится с изменением толщины коллектора для каждой из геологических моделей. В рамках моделирования была изучена разрешающая способность метода к изменению толщины углеводородонасыщенного коллектора $(5,10$ и 15 м). Необходимо отметить, что для того, чтобы приблизить синтетическое моделирование к реальным условиям инверсии полевых данных, когда наличие тонкого пласта-коллектора заранее неизвестно, проводимость коллектора суммировалась с проводимостью вмещающей толщи.

Очевидно, что успех решения геологической задачи с использованием методов геоэлектрики зависит от уровня ЭМ помех. Поэтому, чтобы приблизить синтетические кривые (рассчитанные путем решения прямой задачи электроразведки от выбранных эталонных моделей) к наблюденным полевым, их необходимо «зашумить». Иными словами, наложить электромагнитные помехи, которым подвержены реальные полевые данные.

ЭМ шум можно разделить на два основных типа природный (аддитивный) и искусственный (мультипликативный). Наиболее отрицательное влияние на данные ЗСБ наносит искусственный шум ввиду бо́льшей амплитуды (до первых вольт). На урбанизированных территориях уровень искусственного (индустриального) ЭМ шума может превышать уровень полезного сигнала.

Аддитивный шум порождается природными явлениями, такими как грозовая и электромагнитная планетарная активность. Для естественных источников шум частотой ниже 1 Гц возникает в основном из-за взаимодействия магнитного поля Земли и плазмы, излучаемой Солнцем. Бо́льший вклад в сигналы ЗСБ вносит собой спектр шумов выше 1 Гц. Основным источником шума с частотой более 1 Гц являются грозовые разряды, так называемые «атмосферики». К аддитивному шуму также относится ЭМ шум микроэлектроники измерительного прибора.

Мультипликативный или индустриальный шум, как правило, возникает вследствие наличия линий электропередач. Частота индустриального шума обычно составляет 50-60 Гц. Однако частота может меняться ввиду изменения нагрузки электрической линии. Кроме того, к индустриальному шуму относятся и спектральные пики (> 1000 Гц), обусловленные передатчиками сотовой связи, локаторами, военными приборами и т.д. [20].

Многие исследователи для имитации естественного и искусственного шумов используют ряд математических алгоритмов. Например, для имитации мультипликативного шума используется последовательность нормально распределенных случайных чисел. Среднее значение чисел этой последовательности всегда равно единице, а среднеквадратическое отклонение каждого значения выбирается исходя из 
предполагаемой погрешности измерений. На каждой временной задержке ЭДС переходного процесса умножается на случайное число из этой последовательности.

Аддитивный шум может быть представлен Гауссовым распределением [21].

В данном исследовании использовался иной вид зашумления. Преимуществом используемой технологии является то, что на синтетические данные будет накладываться не идеализированный, а реальный, наблюденный в ходе полевых работ ЭМ шум. Верхней границей накладываемого приведенного шума является 2 нВ. Указанное значение является максимальным уровнем ЭМ помех для 80 \% данных ЗСБ, полученных на юге Сибирской платформы. Для оставшихся $20 \%$ данных уровень помех значительно превышает уровень полезного сигнала, что делает поставленные перед ЗСБ задачи заведомо нерешаемыми. Для анализа уровня ЭМ помех исследуемых территорий использовался архив данных ЭМ зондирований, включающий более 80000 индукционных переходных характеристик ЗСБ [8].

Следующим этапом после генерирования множества кривых ЗСБ с разным уровнем наложенных ЭМ помех является инверсия каждой кривой. Априори считаем, что синтетические кривые заранее освобождены от вклада трехмерных неоднородностей, поэтому применение одномерной инверсии оправдано. На основе результатов инверсии будет оцениваться ошибка определения УЭС целевого горизонта в зависимости от уровня ЭМ помех.

Указанный подход заключается в поступательном усложнении геоэлектрической модели. Изначально интервал подсолевых отложений представлен одним общим слоем. Инверсия осуществляется в пределах всех присутствующих в модели слоев. Далее закрепляется проводимость надсолевой и соленосной части разреза и проводится детализация подсолевого интервала путем его разбиения на тонкие горизонты. Зачастую подсолевая часть отложений подразделяется на верхнемотскую, среднемотскую, нижнемотскую свиты и отложения рифея (в случае его наличия в разрезе). Оценивается возможность перераспределения проводимости между горизонтами.

По результатам решения обратной задачи получен набор геоэлектрических параметров целевого интервала для нескольких вариантов зашумления каждой модели (по 100 моделей для каждого уровня зашумления). Такой подход позволяет получить устойчивое решение обратной задачи. Для дальнейшего анализа полученного результата рассчитывалась относительная погрешность определения удельного электрического сопротивления целевого горизонта.

\section{Результаты}

Результаты моделирования сведены в виде номограмм зависимости ошибки определения УЭС продуктивной толщи от толщины пласта-коллектора и уровня (амплитуды) помех, накладываемых на синтетические сигналы ЭМ помех (рис. 4). Ошибка определения УЭС продуктивной толщи в результате инверсии измеряется в Ом·м, но в данном случае представлена в процентном отношении относительно ее истинного УЭС.

Из анализа номограмм следует, что наиболее благоприятны к применению ЗСБ геологические условия Непского свода. Важно отметить, что ошибка определения УЭС уменьшается при увеличении толщины коллектора, но даже при высоком уровне ЭМ помех (от $70 \%$ ) и толщиной от 5 до 15 м составляет 7-8\%.

Относительно невысокая погрешность определения УЭС методом ЗСБ продуктивной толщи, вмещающей коллектор характерна и для условий АнгароЛенской ступени. При уровне ЭМ помех до $60 \%$

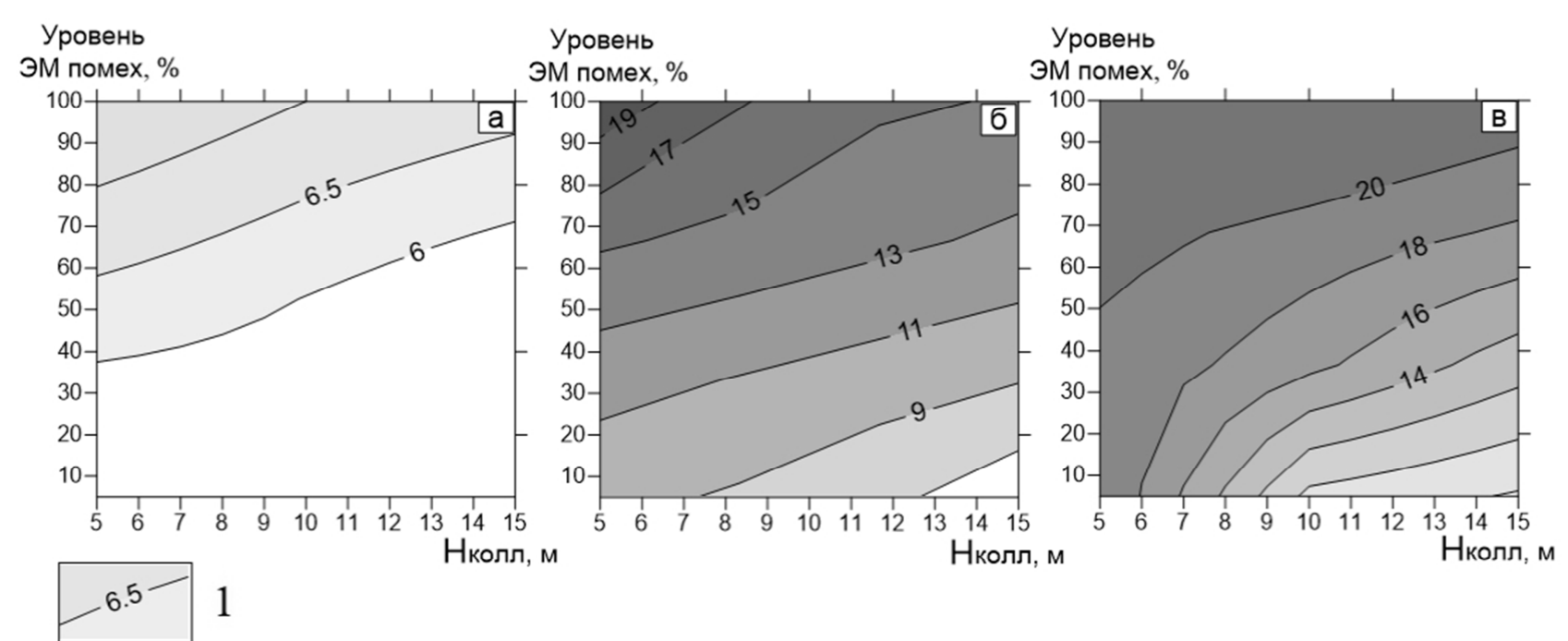

Puc. 4. Номограммы зависимости ошибки определения УЭС продуктивной толщи от толщины коллектора и уровня накладываемых на синтетические кривые ЭМ помех: $A$ - Непский свод; $D$ - Ангаро-Ленская ступень; $B$ - Камовский свод. Условные обозначения: 1 - изолинии погрешности определения УЭС продуктивной толщи, \%. 
ошибка составляет менее $14 \%$.

В геологических условиях Камовского свода ошибка определения УЭС продуктивной толщи значительно выше, чем в первых двух рассматриваемых случаях. Даже при уровне помех от 40 \% погрешность определения сопротивления вмещающей коллектор толщи составляет 18-20\%. В рассматриваемых геологических условиях толщина коллектора имеет принципиальное значение при определении УЭС. Указанная закономерность может объясняться слабой контрастностью исследуемого горизонта на фоне перекрывающих отложений. Так, геоэлектрические свойства слабо проводящей толщи, включающей коллектор толщиной менее 10 м, невозможно определить с погрешностью менее $10 \%$.

В условиях Камовского свода при уровне ЭМ помех более $60 \%$ (более 1,2 нВ) и толщине коллектора менее 7 м прогноз насыщения затруднителен ввиду погрешности определения УЭС, равной разнице между сопротивлением углеводородонащенного (11-13 Ом·м) и водонасыщенного (7-8 Ом·м) коллекторов.

\section{Выводы}

В результате проведенных исследований предложен новый современный численный подход для оценки рисков успеха решения геологической задачи методом ЗСБ, ориентированный на конкретные геологогеоэлектрические и помеховые условия исследуемой территории.

В результате одномерного синтетического моделирования и на основании практического опыта следует вывод, что метод ЗСБ наиболее эффективен в геологических условиях Непского свода ввиду небольшой толщины перекрывающих отложений и относительно высокой контрастности УВ-насыщенной мотской свиты и вмещающих отложений. Незначительно бо́льшая ошибка определения УЭС вмещающей тонкий коллектор толщи по данным ЗСБ характерна для условий Ангаро-Ленской ступени. Данный факт объясняется бо́льшей глубиной залегания коллектора, что уменьшает возможности метода к его выделению на фоне перекрывающих отложений. Однако даже при таких условиях проводимость продуктивного горизонта уверенно определяется по результатам инверсии. Меньшей чувствительностью к изменению геоэлектричеких свойств подсолевой части разреза метод ЗСБ обладает в геологических условиях Камовского свода. Ухудшение точности определения УЭС продуктивного горизонта обусловлено большой толщиной перекрывающих осадков.

Исследования проводились в рамках интеграционной программы ИНЦ СО РАН «Фундаментальные исследования и прорывные технологии как основа опережающего развития Байкальского региона и его межрегиональных связей» (подраздел 73: «Геология месторождений углеводородного сырья, фундаментальные проблемы геологии и геохимии нефти и газа, научные основы формирования сырьевой базы тради- ционных и нетрадиционных источников углеводородного сырья»).

\section{ЛИТЕРАТУРА}

1. Тюрин, Ю. И. Физика. Оптика / Ю. И. Тюрин, И. П. Чернов, Ю. Ю. Крючков. - Томск: ТПУ, 2009. - 240 с.

2. Горностаев, В. П. Опыт применения метода ЗСБ в восточной части Иркутского амфитеатра / В. П. Горностаев, В. М. Панкратов, Б. И. Рабинович // Геология и геофизика. 1973. - №73. деп.

3. Возможности метода ЗСБЗ при изучении палеозойских отложений Сибирской платформы и поисках в них залежей нефти и газа / А. К. Захаркин [и др.] // VIII Всесоюз. науч.техн. геофизическая конференция: Тезисы докладов. Тюмень. $-1976 .-$ С. 16-18.

4. Тархов, А. Г. Комплексирование геофизических методов / А. Г. Тархов, В. М. Бондаренко, А. А. Никитин. - Москва: Недра, 1982. - 295 с.

5. Вахромеев, Г. С. Методика нестационарных электромагнитных зондирований в рудной электроразведке / Г. С. Вахромеев, Н. О. Кожевников. - Иркутск: Изд-во: Иркут, 1988. $-224 \mathrm{c}$.

6. Матвеев, Б. К. Электроразведка: учебник для вузов / Б. К. Матвеев. - Москва: Недра, 1990. - 368 с.

7. Современная практическая электроразведка / А. В. Поспеев [и др.]. - Сень. - Новосибирск: Академическое изд-во «Гео», 2018. $-231 \mathrm{c}$.

8. Гусейнов, Р. Г. Система оценки качества сигналов нестационарных электромагнитных зондирований: автореф. дис. канд. геол.-мин. наук : 25.00.35 / Гусейнов Роман Гасымович. - Иркутск: ИРНИТУ, 2014. - 24 с.

9. Семинский, И. К. Оптимизация методики ЗСБ на предполевом и интерпретационном этапах средствами 3D моделирования: автореф. дис канд. геол.-мин. наук : 25.00.10/ Семинский Игорь Константинович. - Иркутск: ИРНИТУ, 2017. $-24 \mathrm{c}$.

10. McNeill, J. D. Application of transient electromagnetic techniques / J. D. McNeill. - Canada: Geonics Limited, 1980. $17 \mathrm{p}$.

11. Дикмарова, Л. П. Анализ геометрии установок индуктивных методов электроразведки / Л. П. Дикмарова. - Киев: Наукова думка, 1968. - $156 \mathrm{c.}$

12. Тригубович, Г. М. 3D электроразведка становлением поля / Г. М. Тригубович, М. Г. Персова, Ю. Г. Соловейчик. - Новосибирск: Наука, 2009. - 214 с.

13. Подход к инверсии высокоплотных электромагнитных зондирований для проводящих разрезов Западной Сибири / В. С. Емельянов [и др.] // Вопросы естествознания. Специальный выпуск. - 2017. - №1(13). - С. 47-55.

14. Ваньян, Л. Л. О некоторых причинах искажений кривых зондирований становления поля / Л. Л. Ваньян, В. М. Давыдов, Е. И. Терехин // Прикладная геофизика. - 1965. - №41. - С. 84-94.

15. Буддо, И. В. Тонкослоистые модели при изучении коллекторов в осадочном чехле методом зондирований становлением поля в ближней зоне - методика и результаты интерпретации (на примере юга Сибирской платформы) : автореф. дис. канд. геол.-мин. наук : 25.00.10 / Буддо Игорь Владимирович. - Иркутск, 2012. - 16 с.

16. Тектонофизический подход к анализу геологогеофизических данных на газоконденсатных месторождениях со сложным строением платформенного чехла / К. Ж. Семинский [и др.] // Геодинамика и тектонофизика. - 2018. - Т. 9. - № 3. - С. 587-627. 
17. Шемин, Г. Г. Геология и перспективы нефтегазоносности венда и нижнего кембрия центральных районов Сибирской платформы (Непско-Ботуобинская, Байкитская антеклизы и Катангская седловина) / Г. Г. Шемин. - Новосибирск: СО РАН, 2007. - 467 с.

18. Карта нефтегазоносности Сибирской платформы / сост. и подгот. к печати СНИИГГиМС г. Новосибирска ; гл. ред. В. С. Старосельцев. - $1: 2500000$. - Изд.: Гео, 2012.

19. Дахнов, В. Н. Геофизические методы определения коллекторских свойств и нефте-газонасыщения горных пород /

Федеральное государственное бюджетное учреждение науки Институт земной коры Сибирского отделения РАН, 2. Иркутск

Иркутский научный центр Сибирского отделения РАН,

2. Иркутск

ООО «СИГМА-ГЕО», г. Иркутск

Семинский Игорь Константинович, кандидат геологоминералогических наук, ведущий инженер

E-mail: iseminskiy@mail.ru; Тел.: +7 (3952) 427000

Буддо Игорь Владимирович, кандидат геологоминералогических наук, научный сотрудник

E-mail: igor.buddo@yandex.ru; Тел.: +7 (3952) 427000

Федеральное государственное бюджетное учреждение науки Институт земной коры Сибирского отделения РАН, г. Иркутск;

Мурзина Екатерина Викторовна, ведущий инженер E-mail: geomurzina@inbox.ru; Тел.: +7 (3952) 427000

ООО «СИГМА-ГЕО», г. Иркутск

Селяев Василий Андреевич, геофизик

E-mail: v.a.selyaev@gmail.com; Teл.: +7(3952)54 6399
В. Н. Дахнов. - Москва: Недра, 1985. - 310 с.

20. Large scale hydrogeological investigation in the Beder area A case study / E. Auken [et al.] // Proc. Symp. on the Appl. of Geophys to Engineering and Environmental Problems. Boston. 1994. - P. 615-627.

21. Кожевников, Н. О. Совместная инверсия данных МПП с учетом индукционно-вызванной поляризации / Н. О. Кожевников, Е. Ю. Антонов // Геология и геофизика. - 2009. №2. - C. 181-90.

RAS, Siberian Branch, Inst Earth's Crust, Irkutsk $O O O$ «SIGMA-GEO» Irkutsk

Irkutsk Scientific Center, Siberian Branch of RAS, Irkutsk

Seminskiy I. K., Candidate of the Geological and Mineralogical Sciences, the lead engineer

E-mail: iseminskiy@mail.ru

Tel.: +7 (3952) 427000

Buddo I. V., Candidate of the Geological and Mineralogical

Sciences, researcher

E-mail: igor.buddo@yandex.ru

Tel.: +7 (3952) 427000

RAS, Siberian Branch, Inst Earth's Crust, Irkutsk

Myrzina E. V., the lead engineer

E-mail: geomurzina@inbox.ru

Tel.: +7 (3952) 427000

$O O O \ll S I G M A-G E O »$ Irkutsk

Selyaev V. A., geophysics

E-mail:v.a.selyaev@gmail.com

Tel.: +7 (3952)546399 